\title{
Hypoglycemic and hypolipidemic effects of Aerva lanata (Linn.) on alloxan induced diabetic rats
}

\author{
Ramalingam Vidhya ${ }^{1,2}$, Rajangam Udayakumar ${ }^{1 *}$ \\ ${ }^{1}$ Department of Biochemistry, Government Arts College (Autonomous), Kumbakonam-612 001, Tamilnadu, India. \\ ${ }^{2}$ Department of Biochemistry, Dharmapuram Gnanambigai Government Arts College for Women, Mayiladuthurai-609 001, Tamilnadu, India.
}

\section{ARTICLE INFO \\ Article history: \\ Received on: 09/05/2016 \\ Revised on: $06 / 07 / 2016$ \\ Accepted on: 01/08/2016 \\ Available online: 23/10/2016}

Key words:

Aerva lanata, alloxan,

flower, root, diabetes

meilltus, hypoglycemic,

hypolipidemic.

\begin{abstract}
Diabetes mellitus is a chronic disorder of carbohydrate, protein, fat and mineral metabolism. The antidiabetic potential of aqueous extracts flower and root of Aerva lanata was evaluated in alloxan induced diabetic rats Alloxan $(150 \mathrm{mg} / \mathrm{kg} \mathrm{bw})$ induced diabetic rats showed a hyperglycemic state that led to various biochemical and metabolic alterations. The aqueous extract of flower and root of A. lanata $(200 \mathrm{mg} / \mathrm{kg} \mathrm{bw})$ was administrated orally to diabetic rats for 45 days. In this study, the levels of fasting blood glucose, glycated hemoglobin $\left(\mathrm{HbA}_{1} \mathrm{C}\right), \mathrm{C}$-reactive protein (CRP), total cholesterol, triglycerides (TG), low density lipoprotein (LDL), very low density lipoprotein (VLDL), urea, and creatinine were significantly increased in diabetic rats. Body weight, hemoglobin, insulin, C-peptide and protein levels in blood were significantly decreased in alloxan induced diabetic rats. After the administration of extracts of flower and root of $A$. lanata to diabetic rats showed significantly restore the levels as normal rats. The antidiabetic effect of $A$. lanata was compared with strandard drug glibenclamide $(1 \mathrm{mg} / \mathrm{kg}$ bw) treated rats. From this study, we concluded that the aqueous extract of $A$. lanata root have more antidiabetic effect when compared with flower extract. Therefore, the flower and root of $A$. lanata may be used as the alternative medicine for the treatment of diabetes mellitus.
\end{abstract}

\section{INTRODUCTION}

Plants have been the major source of drugs in Indian and other ancient systems of medicine in the world. In the last few years there has been an exponential growth in the field of herbal medicine and these drugs are gaining popularity in both developing and developed countries because of their natural origin and less side effects. Many traditional medicines are derived from medicinal plants, minerals and organic matter [1]. A number of medicinal plants, traditionally used for over 1000 years named rasayana are present in herbal preparations of Indian traditional health care systems [2]. In Indian systems of medicine most practitioners formulate and dispense their own recipes. The World Health Organization (WHO) has listed 21,000 plants, which are used for medicinal purposes around the world. India is the largest producer of medicinal herbs and is

\footnotetext{
* Corresponding Author

Dr. Rajangam Udayakumar, Assistant Professor, Department of Biochemistry, Government Arts College (Autonomous), Kumbakonam612 001, Tamilnadu, India.Email: udayabiochem @yahoo.co.in Phone : +919788755968
}

called as botanical garden of the world [3]. Currently, many research work focuses on herbal drug preparations and plants used in the treatment of diabetes mellitus is a major crippling disease in the world. The global prevalence of diabetes is estimated to increase from $4 \%$ in 1995 to $5.4 \%$ by the year 2025 . Studies were conducted in India in the last decade have highlighted that not only is the prevalence of diabetes is high but also that it is increasing rapidly in the urban population [4]. It is estimated that there are approximately 33 million adults with diabetes in India. This number is likely increase to 57.2 million by the year 2025 . Diabetes mellitus is a group of metabolic alterations characterized by hyperglycemia resulting from defects in insulin secretion or action. It is made up of two types such as Type I and Type II. Type I diabetes often referred to as juvenile diabetes, is insulin dependent and known to affect only $5 \%$ of the diabetic populations. Type II diabetes is non-insulin dependent, usually develops in adults over the age of 40. It has already been established that chronic hyperglycemia of diabetes is associated with long term damage, dysfunction and failure of organs, especially the eyes (retinopathy), kidneys (nephropathy), nerves (neuropathy), heart (coronary heart disease) and blood vessels (peripheral vascular diseases) [5]. 
It has an adverse effect on carbohydrate, lipid and protein metabolism resulting chronic hyperglycemia and abnormality of lipid profile, which leads to series of secondary complications including polyuria, polyphasia, ketosis, glycoma and vascular diseases. In spite of the introduction and extensive utilization of hypoglycemic agents, diabetes and the related complications continue to be a major health problem worldwide, which is affecting nearly $10 \%$ of the population all over the world [7] and considered as a major cause of high economic loss which can in turn impede the development of nations [8]. It is projected to become one of the world's main disablers and killers within the next 25 years. Environmental factors such as diet, obesity and sedentary life style increase the risk of diabetes. Other important risk factors include high family aggregation, insulin resistance, nutritional status, age and lifestyle change due to urbanization [9]. The management of diabetes is a global problem until now and successful treatment is not yet discovered [10]. Currently available therapy for diabetes includes insulin and various oral hypoglycemic agents such as sulfonylureas, metformin, glucosidase inhibitors, troglitazone, etc. But these are reported to produce serious adverse side effects such as liver problems, lactic acidosis and diarrhea [11]. About 800 plant species have been reported to possess antidiabetic properties. Aerva lanata (Linn.) is an important medicinal plant of Amranthaceae family and known as polpala is a prostrate to decumbent sometime erect herb, found throughout tropical India as a common weed in field and wasteland [12]. The plant is used for curing diabetes, anthelmintic, demulcent and it is helpful in lithiasis, cough, sore throat and wound healing. The plant has been used as diuretic, anti-diabetic, expectorant and hepato-protective in traditional system of medicine [13]. The plant also possesses antimicrobial and cytotoxicity activity [14], diuretic [15], urolithiasis [16] and antiinflammatory [17] activities. It has been reported that Canthin-6one and $\beta$-carboline alkaloids were isolated from leaves of $A$. lanata [18]. The plant has been reported to possess antiinflammatory, diuretic and nephroprotective actions and alcoholic extract of shoots of $A$. lanata has also shown significant antidiabetic activity. A number of Indian medicinal plants have been used for their antidiabetic activity in the traditional system of medicine, but not all of them have been reported on scientifically [19]. There is no detailed study on antidiabetic activity of leaf, flower and root of A. lanata. So the present study was aimed to determine the antidiabetic effect of aqueous extracts of flower and root of A. lanata on alloxan induced diabetic rats.

\section{MATERIALS AND METHODS}

\subsection{Collection and preparation of plant material}

The medicinal plant Aerva lanata was collected from in and around Mayiladuthurai at Nagapattinum District, Tamilnadu, India. The plant was identified and authenticated by Dr. S. John Britto, Director, Rapinat Herbarium and Centre for Molecular Systematics, Department of Botany, St. Joseph's College, Tiruchirappalli, Tamilnadu, India. The leaf, flower and root of $A$. lanata were separated and washed thoroughly in running tap water to remove soil particles and adhered debris and then finally washed with sterile distilled water. The leaf, flower and root of $A$. lanata were dried under shade separately and ground well into powder. The powdered materials were stored in air tight containers till the time of use.

\subsection{Preparation of aqueous extracts}

$30 \mathrm{~g}$ powder of leaf, flower and root were soaked separately in distilled water for 12 to 16 hours and boiled and then it was filtered through muslin cloth and then Whatmann no. 1 filter paper. The aqueous extracts were concentrated and made the final volume to one-fifth of the original volume [20]. The paste form of extracts was stored in air tight container at $4^{\circ} \mathrm{C}$ until the time of use.

\subsection{Acute oral toxicity study}

Acute oral toxicity study was conducted as per the OECD Guidelines 423 (acute class toxic class method) [21]. The female wistar albino rats weight about 140-160 g (6-8 weeks) were selected and divided into 4 groups with 6 rats in each group. Animals were fasted overnight, but allowed water ad libitum. Group 1 being the control group and received only distilled water and the groups 2, 3 and 4 were the test group and received aqueous extracts of leaf, flower and root of A. lanata at the dose of $2000 \mathrm{mg} / \mathrm{kg}$, p.o. Since the formulation is relatively non toxic in clinical practice the highest dose of $2000 \mathrm{mg} / \mathrm{kg}$, p.o (as per OECD guidelines "unclassified") was used in the acute toxicity study. All the animals were observed at the time interval of 1, 2, 4, 6 and 24 hrs from 2-14th day, then sacrificed 15th day for gross pathological examination of different organs including heart, lungs, liver, kidneys, sex organs and brain. The animals were observed closely for behavioral toxicity. There is no toxicity was observed in behavior and differentiation in organs.

\subsection{Oral glucose tolerance test}

Oral glucose tolerance test was performed by the method of Du and Karr [22]. The overnight fasted rats were divided into 5 groups of six rats each, pretreatment fasting blood glucose levels of each group were evaluated. Group 1 served as a control, the doses of 100, 200 and $300 \mathrm{mg} / \mathrm{kg}$ bw of aqueous leaf, flower and root extracts of $A$. lanata were given orally to the groups 2, 3 and 4 respectively. Blood glucose level of each group was evaluated after 1 hour of the treatment and considered as $0 \mathrm{~h}$ value. $2 \mathrm{~g} / \mathrm{kg}$ bw of glucose solution was given to all the groups and their blood samples were withdrawn from retro-orbital site at intervals of 1, 2 and $3 \mathrm{~h}$ of glucose administration.

\subsection{Experimental animals}

Albino wistar rats weight ranges between 150-200 g of both sexes were used in this study. They were housed in polypropylene cages under standard laboratory conditions (12-h light/ 12 -h dark cycle, $21 \pm 2{ }^{\circ} \mathrm{C}$, and relative humidity $55 \%$ ). The animals were given standard rodent pellets and water ad libitum. 
The rats were acclimatized to laboratory condition for 7 days before commencement of experiment. Ethical clearance for handling animals for this study was obtained from Institutional Animal Ethical Committee (IAEC) of SASTRA University, Thanjavur, Tamilnadu, India. The experiments were conducted as per the guidelines of CPCSEA, Chennai, India. (Approval no: 211/ SASTRA /IAEC/RPP) .

\subsection{Induction of diabetes mellitus}

Diabetes was induced by intraperitoneal injection of alloxan at the dose of $150 \mathrm{mg} / \mathrm{kg}$ bw. The alloxan was dissolved in distilled water, and then used to induce diabetes mellitus in rats. Fasting blood glucose of the animals was measured after 14 days of alloxan injection using glucometer. Rats with fasting blood glucose above $200 \mathrm{mg} / \mathrm{dl}$ were considered as diabetic rats and used for further study.

\subsection{Drug administration}

After 14 days of alloxan induction, the aqueous extract of flower and root of A. lanata were administered orally through intragastric tube at the dose of $200 \mathrm{mg} / \mathrm{kg}$ body weight.

Group I: Normal control - received only distilled water during the experimental period.

Group II: Diabetic control

Group III: Diabetic rats were daily treated with A. lanata flower extract (200 $\mathrm{mg} / \mathrm{kg}$ body weight) dissolved in distilled water by orally through intragastric tube for 45 days.

Group IV: Diabetic rats were daily treated with $A$. lanata root extract $(200 \mathrm{mg} / \mathrm{kg}$ body weight) dissolved in distilled water by orally through intragastric tube for 45 days.

Group V: Diabetic rats were daily treated with standard drug glibenclamide ( $1 \mathrm{mg} / \mathrm{kg}$ body weight) dissolved in distilled water by orally through intragastric tube for 45 days.

\subsection{Collection of blood sample}

After the experimental period, the animals were kept fasted overnight and sacrificed by cervical dislocation under mild anesthesia. Blood was collected on decapitation and plasma and serum were separated by centrifugation at $2500 \mathrm{rpm}$ for $15 \mathrm{~min}$. The collected plasma and serum samples were used for various biochemical estimations.

\subsection{Biochemical studies}

Blood glucose was estimated by the method of Folins $\mathrm{Wu}$ [23]. Total hemoglobin and glycated hemoglobin were estimated by the methods of Drabkin and Austin [24] and Sudhakar Nayak and Pattabiraman [25] respectively. Plasma insulin was analyzed by the method of radio immunoassay [Diasorin, Italy]. Plasma C-peptide was estimated by the method of radioimmunoassay kit - [Missouri, USA]. C-reactive protein was determined by the method of Singer [26]. The protein content was estimated by the method of Lowry et al. [27]. Serum cholesterol was determined by Zak's method [28], triglyceride was estimated by the method of Foster et al. [29] and HDL cholesterol was determined by the method of Friedewald et al. [30]. Urea and creatinine were estimated by DAM and Jaffe's methods, respectively [31, 32].

\subsection{Statistical analysis}

The results of the present study were subjected to statistical analysis and all the results were expressed as means \pm SE. The statistical significance was evaluated by one way analysis of variance (ANOVA) using SPSS (statistical package for social sciences) Ver. 11 and the individual comparison were obtained by Duncan's Multiple Range Test (DMRT). The values were considered statistically significant at $5 \%$ level $(\mathrm{p} \leq 0.05)$. Values with identical letter are not significant different according to DMRT at $5 \%$ level.

\section{RESULTS}

\subsection{Acute oral toxicity}

Aqueous extracts of leaf, flower and root of A. lanata administered rats showed no mortality or behavior changes at the single dosage of $2000 \mathrm{mg} / \mathrm{kg}$ bw during 14 days of study. Hence there is no lethal and toxic effect was observed on plant extracts treated rats.

\subsection{Oral glucose tolerance test}

The oral glucose tolerance test was evaluated in normal rats by treated with different concentrations $(100 \mathrm{mg}, 200 \mathrm{mg}$ and $300 \mathrm{mg} / \mathrm{kg} \mathrm{bw}$ ) of leaf, flower and root extracts of A. lanata. The blood glucose level was estimated at 0, 1,2 and 3 hours. The plant extracts treated rats suppress the increases of blood glucose levels. The highest inhibition of glucose absorption in blood was observed in root $(62.66 \pm 1.18 \mathrm{mg} / \mathrm{dL})$ and flower $(70.66 \pm 0.98$ $\mathrm{mg} / \mathrm{dL}$ ) extracts of $A$. lanata treated groups at the concentration of $200 \mathrm{mg} / \mathrm{kg}$ b.w. when compared to leaf and standard drug glibenclamide (Table 1).

Table 2 showed that the decreased body weight in alloxan induced diabetic rats. After administration of flower and root extracts of $A$. lanata to diabetic rats showed significantly increased body weight when compared with diabetic control rats.

Table 3 showed that the levels of blood glucose, hemoglobin $(\mathrm{Hb})$ and glycated hemoglobin (HbAlc) in normal control and experimental animals. There were observed significantly increased level of blood glucose and glycated hemoglobin in alloxan induced diabetic rats. The administration of aqueous extracts of flower and root of $A$. lanata and glibenclamide to diabetic rats showed decreased level of glucose and glycated hemoglobin and increased levels of hemoglobin. The root and flower extracts treated diabetic rats were showed decreased levels of blood glucose and glycated hemoglobin. Figure 1 showed that the decreased levels of plasma insulin, C-peptide and protein in alloxan induced diabetic rats. In contrast serum C-reactive protein was remarkably elevated in diabetic rats when compared to normal rats. The oral administration of the aqueous extracts of flower and root of $A$. lanata and glibenclamide tends to bring these values back to near normal as like as normal control rats. 
Table 1: Glucose tolerance test at different doses of leaf, flower and root extracts of $A$. Lanata.

\begin{tabular}{|c|c|c|c|c|c|}
\hline Groups & $\begin{array}{c}\text { Dosage of extracts } \\
(\mathrm{mg} / \mathrm{kg} \text { b.w })\end{array}$ & Fasting & $1 \mathrm{hr}$ & $2 \mathrm{hr}$ & $3 \mathrm{hr}$ \\
\hline \multirow{2}{*}{ Group I - Normal } & - & $69.3 \pm 1.90^{\mathrm{a}}$ & $118.3 \pm 1.36^{\mathrm{b}}$ & $90.3 \pm 2.22^{c}$ & $80.6 \pm 2.41^{\mathrm{d}}$ \\
\hline & $100 \mathrm{mg}$ & $81 \pm 0.81^{\mathrm{a}}$ & $112.33 \pm 1.18^{b}$ & $104.33 \pm 1.43^{c}$ & $90 \pm 3.55^{\mathrm{d}}$ \\
\hline \multirow{3}{*}{ Group II - A. lanata Leaf extract } & $200 \mathrm{mg}$ & $80.33 \pm 2.12^{\mathrm{a}}$ & $92.33 \pm 0.98^{b}$ & $87 \pm 3.68^{c}$ & $78 \pm 1.24^{\mathrm{a}}$ \\
\hline & $300 \mathrm{mg}$ & $70.33 \pm 2.22^{\mathrm{a}}$ & $84 \pm 0.94^{b}$ & $78 \pm 1.41^{c}$ & $78 \pm 1.24^{\mathrm{c}}$ \\
\hline & $100 \mathrm{mg}$ & $75.66 \pm 1.18^{\mathrm{a}}$ & $94.33 \pm 2.12^{b}$ & $89.66 \pm 4.27^{\mathrm{c}}$ & $80.33 \pm 0.71^{\mathrm{d}}$ \\
\hline \multirow{3}{*}{ Group III - A. lanata Flower extract } & $200 \mathrm{mg}$ & $75.33 \pm 1.65^{\mathrm{a}}$ & $93 \pm 1.41^{b}$ & $82 \pm 1.24^{c}$ & $70.66 \pm 0.98^{d}$ \\
\hline & $300 \mathrm{mg}$ & $71 \pm 3.39^{\mathrm{a}}$ & $88.33 \pm 1.96^{b}$ & $82 \pm 0.47^{c}$ & $78 \pm 1.24^{\mathrm{d}}$ \\
\hline & $100 \mathrm{mg}$ & $72.33 \pm 2.22^{\mathrm{a}}$ & $124.33 \pm 4.99^{\mathrm{b}}$ & $92.66 \pm 4.83^{c}$ & $81.33 \pm 0.98^{d}$ \\
\hline \multirow{2}{*}{ Group IV-A. lanata Root extract } & $200 \mathrm{mg}$ & $70.33 \pm 2.84^{\mathrm{a}}$ & $96 \pm 3.74^{b}$ & $74.66 \pm 1.43^{c}$ & $62.66 \pm 1.18^{d}$ \\
\hline & $300 \mathrm{mg}$ & $80.33 \pm 2.59^{a}$ & $103.33 \pm 2.68^{b}$ & $80.33 \pm 1.96^{\mathrm{a}}$ & $67.33 \pm 1.78^{c}$ \\
\hline Group V - Glibenclamide (1 mg/kg b.w) & - & $70.6 \pm 2.41^{\mathrm{a}}$ & $114 \pm 2.82^{\mathrm{b}}$ & $91.6 \pm 3.06^{\mathrm{a}}$ & $75.6 \pm 1.18^{\mathrm{a}}$ \\
\hline
\end{tabular}

Values are expressed as means \pm S.E. of six samples from each group.

Values are not sharing a common superscript differ significantly at $5 \%$ level ( $p \leq 0.05)$ using Duncan's Multiple Range Test (DMRT).

Table 2: Effect of root and flower extracts of $A$. lanata on body weight.

\begin{tabular}{|c|c|c|c|c|}
\hline Groups & $\begin{array}{c}\text { Initial body weight } \\
\text { (gm) }\end{array}$ & $\begin{array}{c}\text { Final body weight } \\
\text { (gm) }\end{array}$ & $\begin{array}{c}\text { Change in Body } \\
\text { weight (gm) }\end{array}$ & $\begin{array}{c}\text { Change in Body } \\
\text { weight }(\%)\end{array}$ \\
\hline Group I Normal control & $263.80 \pm 2.42^{\mathrm{a}}$ & $271.25 \pm 2.25^{\mathrm{a}}$ & +7.45 & 2.82 \\
\hline Group II Diabetic control & $267.85 \pm 3.24^{\mathrm{b}}$ & $182.71 \pm 2.24^{b}$ & -85.14 & 31.78 \\
\hline Group III Diabetic + Flower extract $(200 \mathrm{mg} / \mathrm{kg}$ bw) & $219.91 \pm 2.60^{\mathrm{c}}$ & $241.99 \pm 2.30^{\mathrm{c}}$ & +22.08 & 10.04 \\
\hline Group IV Diabetic + Root extract (200mg/kg bw) & $230.88 \pm 3.10^{\mathrm{d}}$ & $240.90 \pm 2.87^{\mathrm{c}}$ & +10.02 & 4.33 \\
\hline Group V Diabetic + Glibenclamide $(1 \mathrm{mg} / \mathrm{kg}$ bw) & $244.33 \pm 2.33^{\mathrm{e}}$ & $273.83 \pm 2.10^{\mathrm{a}}$ & +29.5 & 12.07 \\
\hline
\end{tabular}

Values are expressed as means \pm S.E. of six samples from each group.

Values are not sharing a common superscript differ significantly at 5\% level ( $<<0.05)$ using Duncan's Multiple Range Test (DMRT).

Table 3: Effect of root and flower extracts of A. lanata on blood glucose, hemoglobin and glycated hemoglobin.

\begin{tabular}{|c|c|c|c|}
\hline Groups & $\begin{array}{c}\text { Blood sugar } \\
(\mathrm{mg} / \mathrm{dl})\end{array}$ & $\begin{array}{c}\text { Hemoglobin } \\
\text { (g/dl) }\end{array}$ & $\begin{array}{c}\text { Glycated hemoglobin } \\
\text { (g/dl) }\end{array}$ \\
\hline Group I Normal control & $92.74 \pm 3.64^{\mathrm{a}}$ & $14.37 \pm .56^{\mathrm{b}}$ & $6.01 \pm 0.23^{\mathrm{a}}$ \\
\hline Group II Diabetic control & $286.72 \pm 11.26^{\mathrm{d}}$ & $11.46 \pm 0.45^{\mathrm{a}}$ & $14.07 \pm 0.55^{\mathrm{d}}$ \\
\hline Group III Diabetic + Flower extract $(200 \mathrm{mg} / \mathrm{kg}$ bw $)$ & $143.34 \pm 5.63^{\mathrm{c}}$ & $12.54 \pm .49^{\mathrm{a}}$ & $8.87 \pm 0.34^{\mathrm{c}}$ \\
\hline Group IV Diabetic + Root extract $(200 \mathrm{mg} / \mathrm{kg} \mathrm{bw})$ & $119.44 \pm 4.69^{b}$ & $14.17 \pm .55^{b}$ & $6.52 \pm 0.25^{\mathrm{a}, \mathrm{b}}$ \\
\hline Group V Diabetic + Glibenclamide (1 mg/kg bw) & $101.47 \pm 3.98^{\mathrm{a}, \mathrm{b}}$ & $15.27 \pm .60^{\mathrm{b}}$ & $7.14 \pm 0.28^{b}$ \\
\hline
\end{tabular}

Values are expressed as means \pm S.E. of six samples from each group.

Values are not sharing a common superscript differ significantly at $5 \%$ level ( $\leq \leq 0.05)$ using Duncan's Multiple Range Test (DMRT).

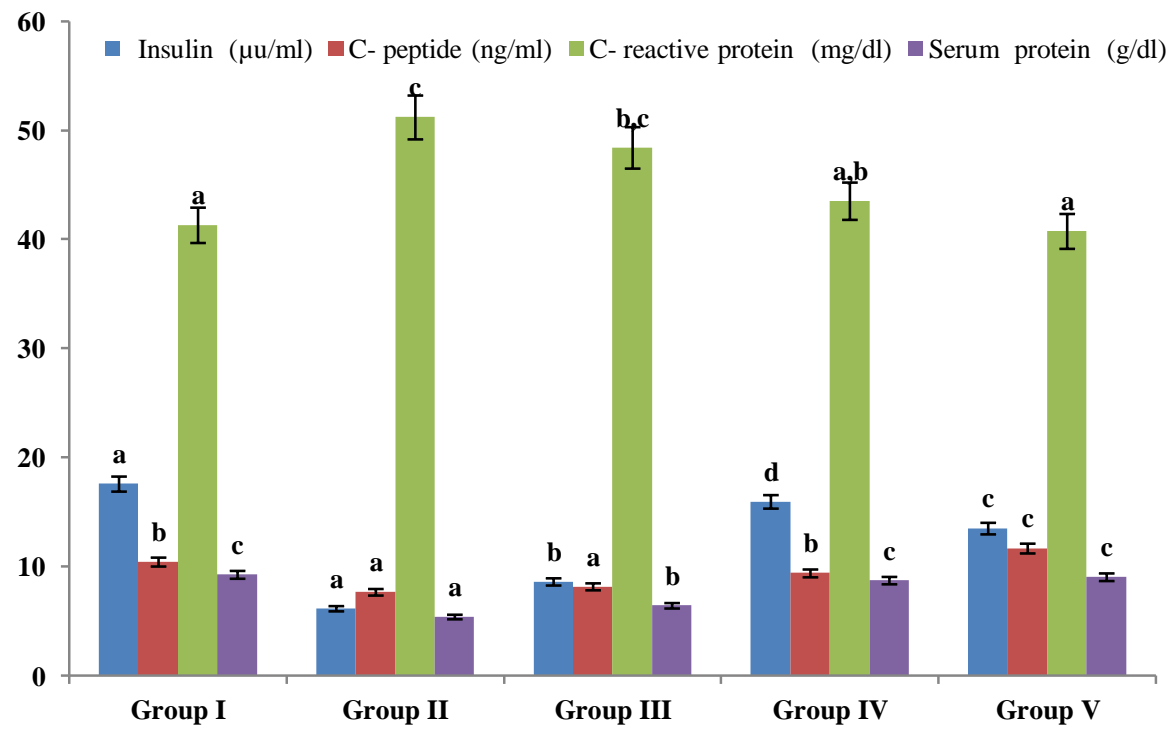

Fig. 1: Effect of root and flower extracts of A. lanata on plasma insulin and C-peptide, C-reactive protein and protein in serum Group I-Normal control; Group II- Diabetic control; Group III- Diabetic +Flower extract (200mg/kg bw); Group IV-Diabetic+Root extract (200mg/kg bw); Group V-Diabetic+Glibenclamide (1mg/kg bw) Values are expressed as means \pm S.E. of six samples from each group 


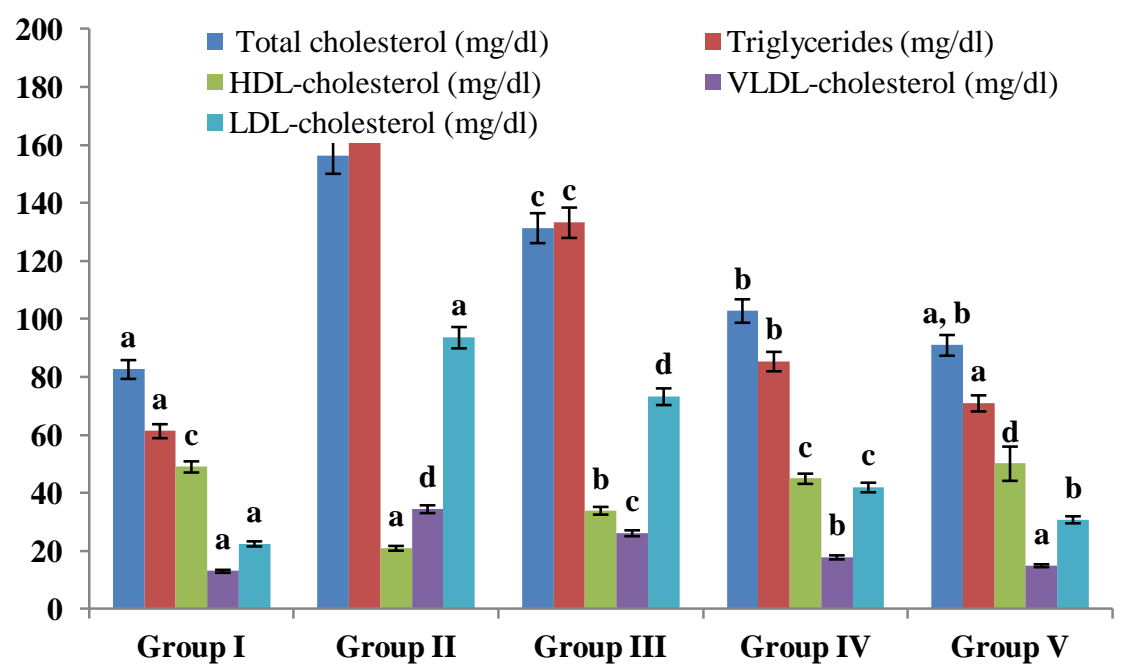

Fig. 2: Effect of root and flower extracts of A. lanata on serum lipid profile Group I-Normal control; Group II- Diabetic control; Group III- Diabetic +Flower extract (200mg/kg bw); Group IV-Diabetic+Root extract (200mg/kg bw); Group V-Diabetic+Glibenclamide (1mg/kg bw) Values are expressed as means $\pm S$.E. of six samples from each group

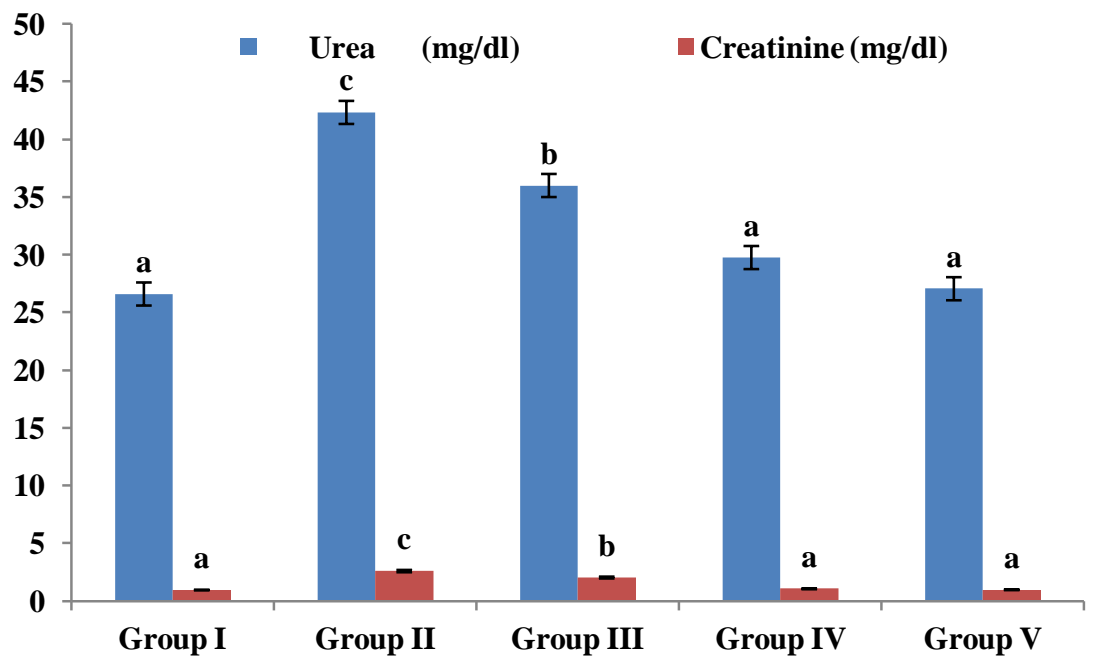

Fig. 3: Effect of root and flower extracts of A. lanata on urea and creatinine in serum (kidney markers) Group I-Normal control; Group II- Diabetic control; Group III- Diabetic +Flower extract $(200 \mathrm{mg} / \mathrm{kg}$ bw); Group IV-Diabetic+Root extract (200mg/kg bw); Group V-Diabetic+Glibenclamide (1mg/kg bw) Values are expressed as means \pm S.E. of six samples from each group

Values are not sharing a common superscript differ significantly at $5 \%$ level $(p \leq 0.05)$ using Duncan's Multiple Range Test (DMRT)

Figure 2 showed the levels of total cholesterol (TC), triglyceride (TG), LDL-cholesterol and VLDL-cholesterol which they were found to be increased significantly in alloxan induced diabetic rats (group II) when compared to normal rats (group I). HDL-cholesterol was found to be significantly decreased in diabetic rats (group II). Oral administration of aqueous extracts of flower and root of A. lanata produced a significant reduction in elevated levels of total cholesterol, TG, LDL-cholesterol and VLDL-cholesterol and also observed an increase in HDLcholesterol. Antihyperlipidemic effect was observed in both root and flower extracts of $A$. lanata treated diabetic rats and it is more or less similar to the standard drug glibenclamide treated rats.

Alloxan causes damages to liver, kidney and pancreas as well as the hyperglycemia related changes which may persist in the tissues. Figure 3 showed that the significantly increased levels of urea and creatinine in diabetic rats when compared with normal control rats. After 45 days of oral administration of flower and root extracts of $A$. lanata to diabetic rats showed significantly decreased levels of urea and creatinine, which was as like as glibenclamide treated rats. 


\section{DISCUSSION}

Diabetes mellitus is a life threading metabolic diseases and it is estimated that its annual incidence rate will continue to increase in the future worldwide. Hyperglycemia is the primary clinical manifestation of micro and macro vascular diabetic complications. Alloxan is a beta cytotoxin, and islets of langerhans of pancreatic beta cells are destroyed and decreased the production of endogenenous insulin secretion and for the reduced utilization of glucose by tissue [33]. In recent years, herbal medicines have started to gain importance as a source of hypoglycemic agents. Marles and Farnsworth estimated that more than 1000 plant species are being used as folk medicine for diabetes [34]. Biological actions of the plant products used as alternative medicines to treat diabetes are related to their chemical composition. Herbal products are flavonoids, terpenoids, phenolic compounds, coumarins, and other constituents which showed reduction in blood glucose levels [35-38]. Several species of medicinal plant possess antidiabetic activity have been described in the scientific and popular literature [39]. Herbal medicines are prescribed due to effectiveness, fewer side effects in clinical experience and relatively low costs [40]. Muscle wasting is an unintentional loss of body weight due to accelerated muscle proteolysis, resulting in loss of body cell mass. Insulin is an important regulating hormone for protein synthesis and proteolysis in skeletal muscle. Insulin resistance or deficiency produces impaired muscle protein turnover and muscle wasting. The uncontrolled diabetes is associated with severe loss of muscle wasting [41]. In the present study, we observed that the significant loss of weight in diabetic rats when compared with normal rats. Granner [42] reported the loss of weight is due to muscle wasting and adipose tissue from excessive breakdown of tissue protein and fatty acids. Dehydration and loss of body weight have been associated with diabetes mellitus [43]. Administration of A. lanata plant extracts showed increases of body weight and it may be due to prevent the loss of muscle and adipose tissue protein and fatty acids degradation [44]. Oral administration of aqueous extract of flower and root of A. lanata to diabetic rats showed decreased level of blood glucose. The root extract was highly decreased blood glucose when compared to flower extract of $A$. lanata. The possible mechanism by which $A$. lanata mediated its antidiabetic effect could be by improvement of pancreatic secretion of insulin from existing beta cells of islets or regenerated beta cells. The hypoglycemic effect of flower and root extract of $A$. lanata was similar with glibenclamide is a standard hypoglycemic drug. Similarly, a number of other plants have also been reported to elicit their antihyperglycemic effects by a stimulatory effect on insulin release [45]. The mechanism of action of hypoglycemic activity of the medicinal plant extract was not studied, however it has been already reported that this hypoglycemic action might be due to modulation of insulin secretion and /or insulin action or could be related to the interference on absorption of dietary carbohydrates as well as disaccarides in small intestine leads to the suppression of meal induced increase of plasma glucose [46]. The glycated hemoglobin was increased in diabetes patients with and without complications. A significant increase in the level of glycated hemoglobin was reported in alloxan induced diabetes. The rate of formation of glycated hemoglobin is directly proportional to the concentration of blood glucose. After 45 days treatment of $A$. lanata extracts significantly reduced glycated hemoglobin and concomitant increase in the level of total hemoglobin in the alloxan induced diabetic rats treated with flower and root of A. lanata as like as glibenclamide treated rats. The estimation of glycated hemoglobin is a well accepted parameter useful in the management and prognosis of the diabetes. The researchers observed increase in the levels of glycated hemoglobin (HbA1c) in diabetic rats is due to the presence of excessive amount of glucose in blood and then react with hemoglobin to form glycated hemoglobin [47, 48]. Bunn et al. [49] reported the mechanism by which increased oxidative stress is involved in the diabetes complications are partially known to include the activation of transcription factors, advanced glycated end products (AGEs) and protein kinase C. Glycated hemoglobin has been found to be increased over a long period of time in diabetic mellitus. C-reactive protein is not normally found in the blood of healthy people. It appears after an injury, infection, or inflammation and disappear when the injury heals or the inflammation. The report suggests that patients with prolong elevated levels of C-reactive protein are at an increased risk for heart disease, stroke, hypertension (high blood pressure), diabetes, and metabolic syndrome (insulin resistance, a precursor of type 2 diabetes) [50]. The researchers reported that patients with elevated basal levels of $\mathrm{C}$-reactive protein are at an increased risk of diabetes [51, 52]. Higher levels of C-reactive protein predict cardiovascular events indicating a possible role for inflammation in the etiology of cardiovascular disease [53]. Mana et al. [54] reported that the hypoglycemic effect of methanol and aqueous extract of aerial part of $A$. lanata may be due to its protective action against alloxan induced damage to the pancreatic beta cells and also possibly because of regeneration of damaged beta cells or increased insulin secretion. Patients with diabetes may have their C-peptide levels measured as a means of distinguishing type I diabetes from type II diabetes or Maturity onset diabetes of the young (MODY) [55]. Measurment of C-peptide can help to determine amount of production of natural insulin, because the $\mathrm{C}$ peptide is secreted in equimolar amounts to insulin. C-peptide levels are measured instead of insulin levels because $\mathrm{C}$-peptide can assess a person's own insulin secretion even if they receive insulin injections and because the liver metabolizes a large and variable amount of insulin secreted into the portal vein but does not metabolise C-peptide. So the C-peptide may be a better measure of portal insulin secretion than insulin itself [56, 57]. A very low level of C-peptide confirms Type I diabetes and insulin dependence and is associated with high glucose variability, hypoglycaemia and increased complications. The test may be less helpful close to diagnosis, particularly where a patient is overweight and insulin resistant, as levels close to diagnosis in Type I diabetes may be high and overlap with those seen in type II 
diabetes [58]. In the present study, serum C-peptide and insulin was profoundly decreased and elevated level of C-reactive protein was observed in diabetic rats. After 45 days treatment of flower and root extract of $A$. lanata increased the amount of insulin and C-peptide and decrease $\mathrm{C}$ - reactive protein levels in alloxan induced diabetic rats, when compared with diabetic untreated rats. Kamalakkannan and Prince [59] suggested that the increase in serum C-peptide levels concomitant with the increase of serum insulin levels in diabetic rats. An increase in both body protein synthesis and break down process occurs in poorly controlled type I diabetic mellitus. The increase in protein breakdown is greater than the increase in protein synthesis resulting in a net protein loss [60]. Glucagon, the hormone determined to be largely responsible for the increased energy expenditure during insulin deprivation in type I diabetic individuals, increases leucine and phenylalanine oxidation and protein breakdown [61-63]. Insulin deficiency leads to various metabolic aberrations in the animals such as decreased protein content. Insulin deficiency causes excessive catabolism of protein and the amino acids released are used for gluconeogenesis [64]. Tissue protein levels depend on the balance between their synthesis and catabolism from the body. Generally, alloxan diabetogenesis was observed to suppress kidney enzyme and protein expression in the kidney. The significant decrease in kidney protein concentration of diabetic rats when compared to the non-diabetic rats could indicate that alloxan diabetogenesis may have suppressed that rat's kidney protein reserve [65]. The decrease in total protein may be due to microproteinuria, which are important clinical markers of diabetic nephropathy [66] and or may be due to increased protein catabolism [67]. Such improvement of serum protein and albumin was previously observed after the oral administration of A. lanata to experimental diabetic rats [68]. It has been established that insulin stimulates the incorporation of aminoacids into proteins [67]. Hyperlipidaemia is a recognized as a common complication of diabetes mellitus. A reduction in insulin secretion causes a variety of derangements in metabolic and regulatory mechanisms leading to accumulation of lipids [69]. The improvements in the lipid profile in diabetic animals after treatment with aqueous extracts of flower and root of A. lanata could be beneficial in preventing lipid metabolism [70]. The concentration of lipids, such as cholesterol, TG, LDL-C and VLDL-C were significantly higher in diabetic rats than in the normal control group [71]. The impairment of insulin secretion results in enhanced metabolism of lipids from the adipose tissue to the blood. Further it has been reported that diabetic rats treated with insulin showed normalized the lipid levels [72]. In the present study, alloxan induced diabetic rats found to be produce increased levels of total cholesterol, triglycerides, LDL-C and VLDL-C, which correlates with earlier findings that there is an increase in lipid levels is observed not only in diabetic rats but also in diabetic patients. Emblica officinalis is also reported to produce hypolipidemic effect in cholesterol fed rabbit and Gymnema sylvestre is reported to produce hypolipidemic effect by inhibition of intestinal absorption of fatty acids in rats [73]. Possible mechanism for decrease lipid levels could be either insulin releasing effect of A. lanata or insulin sensitivity activity, because insulin has been proved to inhibit the activity of the hormone sensitive lipases in adipose tissue and suppresses the release of lipids [74]. The most commonly observed lipid abnormalities in diabetes are hypertriglyceridemia and hypercholesterolemia [75]. This might have occurred in the diabetic rats as a result of lack of insulin which activates the lipase enzymes, hydrolyzing the stored TG and releasing large amounts of fatty acids and glycerol in the circulating blood [76]. Treatment with flower and root extracts of A. lanata $(200 \mathrm{mg} / \mathrm{kg}$, p.o.) not only lowered the TC, TG, LDL and VLDL levels, but also enhanced the HDL-cholesterol which is known to play an important role in the transport of cholesterol from peripheral cells to the liver by a pathway termed "reverse cholesterol transport," and it may be considered to be a cardio protective lipid [77]. An increase in urea level was observed when there is damage to the kidney or the kidney is not functioning properly. Increment of blood urea level with the increment of blood sugar level clearly indicates that the increased blood sugar level causes damage to the kidney [78]. Diabetic hyperglycaemia increases serum urea and creatinine levels are indicating renal dysfunction and reduced glomerular filtration. Alloxan induced rats produced the free radical mediated compounds, to breakdown of liver and plasma proteins that leads to the accumulation of urea nitrogen and associated with increase in creatinine level in experimental diabetes [79].

This response is in agreement with other study, in which they reported that the increased levels of urea in alloxan induced diabetic animals [80]. The increase of urea nitrogen in diabetes may be account by enhanced catabolism of both liver and plasma protein that accompany gluconeogenesis. The alloxan induced diabetic rats treated with aqueous extracts of flower and root of $A$. lanata $(200 \mathrm{mg} / \mathrm{kg}$ b.w) significantly decreased the levels of urea and creatinine, when compared to diabetic rats. The plant has been established that insulin stimulates the incorporation of aminoacids to protein synthesis and decrease in the levels of negative nitrogen balance [81].

\section{CONCLUSION}

In this study, the antidiabetic effect of aqueous extracts of flower and root of A. lanata on alloxan induced diabetic rats was confirmed. Antidiabetic activity was high in root extract treated rats when compared to flower extract of A. lanata. From this study, we concluded that flower and root extracts of $A$. lanata has significance hypoglycemic and hypolipidemic effects.

\section{Financial support and sponsorship: Nil.}

Conflict of Interests: There are no conflicts of interest.

\section{REFERENCES}

1. Grover JK, Yadav S, Vats V. Medicinal plants of India with antidiabetic potential. Journal of Ethnopharmacology. 2002; 81: 81-100. 
2. Scartezzini P, Sproni E. Review on some plants of Indian traditional medicine with antioxidant activity. Journal of Ethnopharmacology. 2000; 71: 23-43.

3. Seth SD, Sharma B. Medicinal plants of India. Indian Journal of Medical Research. 2004; 120: 9-11.

4. Ramachandran A, Snehalatha C, Viswanathan V. Burden of type II diabetes and its complications- the Indian scenario. Current Science. 2002; 83: 1471-1476.

5. Huang THW, Peng G, Kota BP, Li GQ, Yamahara J, Roufogalis BD et al. Anti-diabetic action of Punica granatum flower extract: activation of PPAR-c and identification of an active component. Toxicology and Applied Pharmacology. 2005; 207:160-169.

6. Kumar P, Clark M. Diabetes Mellitus and Other Disorders of Metabolism. In: Clinical Medicine, Sunders WB, editors. 2nd ed. Elsevier, London: 2002, p.1069-1071.

7. Burke JP, Williams K, Narayan KMV, Leibson C, Haffner SM, Stern MP. A population perspective on diabetes prevention: Whom should we target for preventing weight gain. Diabetes Care. 2003; 26:1999- 2004.

8. Mahabir D, Gulliford MC. Use of medicinal plants for diabetes in Trinidad and Tobago. Revista Panamericana de Salud Publica. 1997; 1:174-179.

9. Deepashree BN, Prakash JA. Study on nutritional status of diabetics and associated risk factors. Journal of Human Ecology. 2007; 21: 269-274.

10. Malviya N, Jain S, Malviya S. Antidiabetic potential of medicinal plants. Acta Poloniae Pharmaceutica - Drug Research. 2010; 67(2):113-118.

11. Rajalakshmi M, Eliza J, Priya CE, Nirmala A, Daisy P. Antidiabetic properties of Tinospora cordifolia stem extracts on streptozotocin-induced diabetic rats. African Journal of Pharmacy and Pharmacology. 2009; 3(5):171-180

12. Krishnamurthi A. The wealth of India. Vol. I, CSIR, New Delhi, 2003, p. 92.

13. Kiritikar KR, Basu BD. Indian Medicinal Plants. 1996, p. 20642065.

14. Dulaly C. Antimicrobial activity and cytotoxicity of Aerva lanata. Fitoterapia. 2002; 73: 92-94.

15. Udupihille M, Jiffry MTM. Diuretic effect of Aerva lanata with water, normal saline and coriander as controls. Indian Journal of Physiology and Pharmacology. 1986; 30: 91-97.

16. Rao SG. Evaluation of an experimental model for studying urolithiasis effect of Aerva lanata on urinary stones. Indian Drugs. 1985; 22: 640-643.

17. Vetrichelvan T, Jegadeesan M, Senthil Palaniappan S, Murali NP, Sasikumar K. Diuretic and anti inflammatory activities of Aerva lanata in rats. Indian Journal of Pharmaceutical Sciences. 2000; 62:300-302.

18. Zapesochnaya G. Canthin-6-one and beta-carboline alkaloids from Aerva lanata. Planta Medica. 1992; 58: 192-196.

19. Deshmukh TA, Yadav BV, Badole SL, Bodhankar SL, Dhaneshwar SR. Antihyperglycaemic activity of alcoholic extract of Aerva lanata (L.) A. L. Juss. Ex J. A. Schultes leaves in alloxan induced diabetic mice. Journal of Applied Biomedicine. 2008; 6: 81-87.

20. Parekh J, Nair R Chanda S. Preliminary screening of some folkloric plants from western India for potential antimicrobial activity. Indian Journal of Pharmacology. 2005; 37: 408-09.

21. Organization for Economic Cooperation and Development. The OECD 423 guideline for testing of chemicals acute oral toxicityAcute Toxic Class Method. Paris: France; 2001.

22. Du Vigneaud V, Karr WG. Carbohydrate utilization, rat of disappearance of D-glucose from the blood. Journal of Biological Chemistry. 1925; 66: 281-300.
23. Folin 0, Wu H. A system of blood analysis. Journal of Biological Chemistry. 1919; 38: 81.

24. Nayak SS, Pattabiraman TN. A new colorimetric method for the estimation of glycosylated haemoglobin. Clinica Chimica Acta. 1981; 109: 267- 274.

25. Drabkin DL, and Austin JM. Spectrophotometeric consitants for common haemoglobin derivatives in human, dogs and rabbit blood. Journal of Biological Chemistry. 1932; 98:719-33.

26. Singer J M and Plotz C M. The latex fixation test. I. Application to the serologic diagnosis of rheumatoid arthritis. American Journal of Medicine. 1956; 21:888-92.

27. Lowry $\mathrm{OH}$, Rosebrough NJ, Farr AL, Randall RJ. Protein measurement with the folin phenol reagent. Journal of Biological Chemistry. 1951; 193: 265-275.

28. Zlatkis A, Zak B, Boyle AJ. A new method for the direct determination of serum cholesterol. Journal of Laboratory and Clinical Medicine. 1953; 41: 486.

29. Foster LB, Dunn RT. Stable reagents for determination of serum triglycerides by a colorimetric Hantzsch condensation method. Clinical Chemistry. 1973; 19(3): 338-340.

30. Friedewald WT, Levy RI, Fredrickson DS. Estimation of the concentration of low density lipoprotein cholesterol in plasma, without the use of preparative centrifuge. Clinical Chemistry. 1972; 18(2): 499-502.

31. Girard M, Dreux C. Diaectylmonoxime in the determination of urea. Annales Pharmaceutiques Francaises. 1958; 16: 604.

32. Bonsness RW, Taussky HH. On the colorimetric determination of creatinine by the Jaffe reaction. Journal of Biological Chemistry. 1945; 158: 581-583.

33. Okamoto H, Yamamoto H, Uchigata Y. Streptozotocin and alloxan induce DNA strand breaks and poly (ADP-ribose) synthetase in pancreatic islets. Nature. 1981; 294: 284-6.

34. Marles RJ, Farnsworth NR. Antidiabetic plants and their active constituents. Phytomedicine. 1995; 2(2):137-189.

35. Vessal M, Zal F, Vasi M. Effects of Teucrium polium on oral glucose tolerance test, regeneration of pancreatic islets and activity of hepatic glucokinase in diabetic rats. Archives of Iranian Medicine. 2003; 6: 36-39.

36. Atta-Ur-Rahman, Zaman K. Medicinal plants with hypoglycemic activity. Journal of Ethnopharmacology. 1989; 26: 1-55.

37. Chattopadhyay RR, Sarkar SK, Ganguly S, Banerjee RN, Basu TK. Hypoglycemic and antihyperglycemic effect of leaves of Vinca rosea. Indian Journal of Physiology Pharmacology. 1991; 35(3):145-151.

38. Essawy GS, Sobbhy HM, El-Banna HA. The hypoglycemic effect of volatile oil of some Egyptian plants. Veterinary medical journal Giza. 1995; 43(2):167- 172.

39. Valiathan MS. Healing plants. Current Science. 1998; 75: 1122 1126.

40. Verspohl EJ. Recommended testing in diabetes research. Planta Medica. 2002; 68: 581- 590.

41. Castaneda C. Muscle wasting and protein metabolism. Journal of Animal Sciences. 2002; 80(2): E98-E105.

42. Granner DK. Hormones of the gonads. In: Murray RK, Granner DK, Mayes PA, Rodwell VW, editors. Harper's Biochemistry, (Stamford, CT: Appleton and Lange Press), 1996, p. 566-580.

43. Pupim LB, Heimburger O, Qureshi AR, Ikizler TA, Stenvinkel P. Accelerated lean body mass loss in incident chronic dialysis patients with diabetes mellitus. Kidney International. 2005; 68: 2368-2374.

44. Iweala EEJ, Obidoa O. Effect of a long term consumption of a diet supplemented with leaves of Gongronema latifolium Benth. On some biochemical and histological parameters in male albino rats. Journal of Biological Sciences. 2009; 9(8): 859865. 
45. Latha M, Pari L. Antihyperglycemic effect of Cassia auriculata in experimental diabetes and its effects on key metabolic enzymes involved in carbohydrate metabolism. Clinical and Experimental Pharmacology and Physiology. 2003; 30: 38-43.

46. Ortiz-Andrade RR, Garcia-Jimenez S, Castillo Espana P, RamirezAvila G, Villalobos-Molina R, Estrada-Soto S. Glucosidase inhibitory activity of the methanol extract from Tournefortia hartwegiana: an anti-hyperglycemic agent. Journal of Ethnopharmacology. 2007; 109; 48-53.

47. Alyassin D, Ibrahim KA. Minor haemoglobin fraction and the level of fasting blood glucose. Journal Faculty Medical University of Baghdad. 1981; 23: 373-380.

48. Sheela CG, Augusti KT. Antidiabetic effect of S-allyl cystein sulfoxide from garlic Allium sativum Linn. Indian Journal of Experimental Biology. 1992; 30:523-526.

49. Bunn HG, Gabby KH, Gallop PM. The glycosylation of hemoglobin: relevance to diabetes mellitus. Science. 1978; 200:21-7.

50. Deron Scott J. C - reactive protein: Everything you need to know about it and why it's more important than cholesterol to your health. New York City: McGraw-Hill, 2003.

51. Pradhan AD, Manson JE, Rifai N, Buring JE, Ridker PM. C-reactive protein, interleukin 6 , and risk of developing type 2 diabetes mellitus. Journal of the American Medical Association. 2001; 286 (3): 327-34.

52. Dehghan A, Kardys I, de Maat MP, Uitterlinden AG, Sijbrands EJ, Bootama AH, Stijen T, Hofman A, Schram MT Witteman JC. Genetic variation, C-reactive protein levels, and incidence of diabetes. Diabetes. 2007; 56(3): 872-2.

53. Colhoun H M, Schalkwijk C, Rubens M B, Stehouwer C DA. Creactive protein in type 1 diabetes and its relationship to coronary artery calcification, Diabetes Care. 2002; 25(10): 1813-1817.

54. Mana S, Singhal S, Sharma NK, Singh D. Hypoglycemic effect of Holarrhena antidysenterica seeds on streptozotocin induced diabetic rats. International Journal of PharmTech Research. 2010; 2: 13251329.

55. Jones AG, Hattersley AT. The clinical utility of C-peptide measurement in the care of patients with diabetes. Diabetic Medicine. 2013; 30(7):803-17.

56. Clark PM. Assays for insulin, proinsulin and C-peptide. Annals of Clinical Biochemistry. 1999; 36: 541-564.

57. Shapiro ET, Tillil H, Rubenstein AH, Polonsky KS. Peripheral insulin parallels changes in insulin secretion more closely than Cpeptide after bolus intravenous glucose administration. Journal of Clinical Endocrinology and Metabolism. 1988; 67(5):1094-9.

58. Chandini R, Udayabhaskaran V, Binoy J Paul, Ramamoorthy KP. A study of non-obese diabetes mellitus in adults in a tertiary care hospital in Kerala, India. International Journal of Diabetes in Developing Countries. 2013; 33 (2): 83-85.

59. Kamalakkannan N, Prince PS. The effect of Aegle marmelos fruit extract in streptozotocin diabetes: A histopathological study. Journal of Herbal Pharmacotherapy. 2005; 5: 87-98.

60. Nair KS, Garrow JS, Ford C, Mahler RF, Halliday D. Effect of poor diabetic control and obesity on whole body protein metabolism in man. Diabetologia. 1983; 25(5):400-3.

61. Charlton MR, Nair KS. Role of hyperglucagonemia in catabolism associated with type 1 diabetes: effects on leucine metabolism and the resting metabolic rate. Diabetes. 1998; 47(11):1748-56.

62. Nair KS, Halliday D, Matthews DE, Welle SL. Hyperglucagonemia during insulin deficiency accelerates protein catabolism. American Journal of Physiology. 1987; 253(2 Pt 1): E208-13.

63. Tessari P, Inchiostro S, Barazzoni R, Zanetti M, Vettore M, Biolo G, Iori E, Kiwanuka E, Tiengo A. Hyperglucagonemia stimulates phenylalanine oxidation in humans. Diabetes. 1996; 45(4):463-70.

64. Vasantha kumara V, Shyamala devi CS. Biochemical evaluation of "Tara Keswara Rasa"- An anti diabetic drug in Rats, Indian Drugs. 1998; 35: 140-143.

65. Wilson JD, Foster DW. William's textbook of endocrinology (7th edition) Unger RH, Foster DW, editors. Philadelphia: W. B. Saunders Company. 1985.
66. Mauer SM, Steffes MW, Brown DM. The kidney in diabetes. American Journal of Medicine. 1981; 70: 63-6.

67. Almdal TP, Vilstrup H. Strict insulin therapy normalises organ nitrogen contents and the capacity of urea nitrogen synthesis in experimental diabetes in rats. Diabetlogia. 1988; 31: 114-118.

68. Mansour HA, Newairy AA. Amelioration of impaired renal function associated with diabetes by Balanites aegyptiaca fruits in streptozotocin-induced diabetic rats. J Med Res Inst. 2000; 21: 115 25.

69. Al-Attar AM. Physiological effects of some plant oils supplementation on streptozotocin-induced diabetic rats. Research Journal of Medicine in Medical Sciences. 2010; 5: 55-71.

70. Cho SY, Park JY, Park EM. Alteration of hepatic antioxidant enzyme activities and lipid profile in streptozotocin induced diabetic rats by supplementation of dandelion water extract. Clinica Chimica Acta. 2002; 317:109 - 117 .

71. Rajalingam R, Srinivasan N, Govindarajulu P. Effect of alloxan induced diabetes on lipid profiles in renal cortex and medulla of mature albino rats. Indian Journal of Experimental Biology. 1993; 31: 577-579.

72. Pathak RM, Ansai S, Mahmood A. Changes in chemical composition of intentional brush border membrane in alloxan induced chronic diabetes. Indian Journal of Experimental Biology. 1981; 19: 503-505.

73. Wang LF, Luo H, Miyoshi M, Imoto T, Hiji Y, Sasaki T. Inhibitory effect of gymnemic acid on intestinal absorption of oleic acid in rats. Canadian Journal of Physiology and Pharmacology. 1998; 76:1017.

74. Loci AS, Shaabha M, Khazraji AL, Husain A, Twaija A. Hypoglycemic effect of a valuable extract of artemicisia herb Alba II. Effect of a valuable extract on some blood parameters in diabetic animals. Journal of Ethnopharmacology. 1994; 43:167-171.

75. Pushparaj PN, Low HK, Manikandan J, Tan BKH, Tan CH. Antidiabetic effects of Cichorium intybus in streptozotocin-induced diabetic rats. Journal of Ethnopharmacology. 2007; 111: 430-434

76. Shirwaikar A, Rajendran K, Barik R. Effect of aqueous bark extract of Garuga pinnata Roxb. in streptozotocin nicotinamide induced type II diabetes mellitus. Journal of Ethnopharmacology. 2006; 107: 285290.

77. Levy RI. High-density lipoproteins, an overview, Lipids. 1978; 13: 911-913.

78. Anjaneyulu Muragundla, Chopra Kanwaljit. quercetin, an antioxidant bioflavonoid, attenuates diabetic nephropathy in rats. Clinical and Experimental Pharmacology and Physiology. 2004; 31: 244-8.

79. Salil G, Nevin KG, Rajamohan T. Effect of dietary coconut kernel protein on the liver and pancreas of alloxan-induced diabetic rats: comparison with L-arginine and glibenclamide. Mediterranean Journal of Nutrition and Metabolism. 2012; 5: 127-133.

80. Khushk I, Dahot mo, Baloach SA, Bhutto MA. The evaluation of soybean extracts in alloxan -induced diabetic rabbits. World Applied Sciences Journal. 2010; 8: 22-25.

81. Eskander EF, Jun HW, Ibrahim KA, Abdelal WE. Hypoglycemic effect of an herbal formulation in alloxan induced diabetic rats. Egyptian Journal of Pharmaceutical Sciences. 1995; 36: 253-270.

\section{How to cite this article:}

Vidhya R, Udayakumar R. Hypoglycemic and hypolipidemic effects of Aerva lanata (Linn.) on alloxan induced diabetic rats. J App Biol Biotech. 2016; 4 (05): 048-056. doi: 10.7324/JABB.2016.40508 